НАУКОВИЙ ВІСНИК

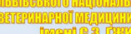

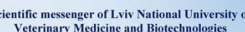

1

$\sqrt{1}$

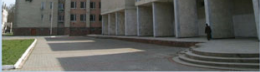

СЕРЯя: ВЕТЕРИНАРНН НАУКИ

Том 23 № 101

2021
Науковий вісник Дьвівського національного університету ветеринарної медицини та біотехнодогій імені С.3. Гжицького. Серія: Ветеринарні науки

\author{
Scientific Messenger of Lviv National University
} of Veterinary Medicine and Biotechnologies. Series: Veterinary sciences

UDC 619:618.33/36 - 008.-079

\title{
Prediction of birth and postpartum pathology in deep-calving heifers by biochemical parameters of blood
}

\author{
L. V. Koreyba
}

Dniprovsky State Agro-Economical University, Dnipro, Ukraine

Article info

Received 21.12.2020

Received in revised form 20.01 .202

Accepted 21.01.2021

Dnipro State Agrarian and Economic University, Serhiya Yefremova Str., 25, Dnipro, 49000, Ukraine.

Tel.: +38-056-68-33-77

E-mail:lyudkorflk@gmail.com
Koreyba, L. V. (2021). Prediction of birth and postpartum pathology in deep-calving heifers by biochemical parameters of blood. Scientific Messenger of Lviv National University of Veterinary Medicine and Biotechnologies. Series: Veterinary sciences, 23(101), 21-25. doi: $10.32718 /$ nvlvet10104

The success of the control of obstetric diseases in cattle depends on the timely implementation of preventive measures, and, in cases of pathology, on diagnosis, effective obstetric care and treatment. A prominent place is given to blood tests among the methods that allow to objectively assess the state of health and the course of the pathological process in animals' bodies. The study of biochemical parameters of blood allows for the assessment of the state of metabolic processes in animals, with high accuracy in establishing the body's general condition and predicting complications and adjusting their prevention and therapy. The goal of the work: our work aimed to study the biochemical parameters of the blood of deep-calving heifers for the prediction, correction, and prevention of obstetric pathology during childbirth and puerperium. The research was carried out on deep-calving heifers of Holstein breed selected on the principle of analogues. Biochemical examination of blood serum was performed in the district laboratory of veterinary medicine. Indicators of protein and mineral metabolism were determined in the blood serum of deep-calving heifers: total protein, carotene, reserve alkalinity, inorganic phosphorus, albumin content, class $M$ immunoglobulins. The obtained research results indicate that the total protein content corresponds to the norm in deep-calving heifers of the Holstein black-spotted breed. The protein coefficient exceeds the standard. There are pronounced deviations in the blood's biochemical parameters: low levels of carotene almost two-fold, reserve alkalinity - 1.91-fold, the total calcium content - by $16.08 \%$ and the ratio of calcium to phosphorus by $17.78 \%$. Since the decrease in carotene content correlates with the predisposition to endometritis, the Holstein black-spotted breed's deep-calving heifers are prone to developing birth and postpartum pathology. For pregnant cows which are predisposed to postpartum obstetric pathology, that occur in weak parturition activity, failure to release the placenta, uterus subinvolution, endometritis and postpartum hypocalcaemia, unfavorable prognostication is the low concentration in blood plasma of general calcium, inorganic phosphorus and carotene.

Key words: heifers, pregnancy, birth and postpartum pathology, biochemical parameters of blood, biochemical research.

\section{Прогнозування родової та післяродової патології у глибокотільних нетелей за біохімічними показниками крові}

\author{
Л. В. Корейба
}

Дніпровський державний аграрно-економічний університет, м. Дніпро, Україна

Успіх боротьби з акушерськими захворюваннями маточного поголів'я великої рогатої худоби залежсть від своєчасного проведення профілактичних заходів, а у випадках появи патологї - від діагностики, ефективного надання акушерської допомоги та проведення лікування. Серед методів, щзо дають можливість об 'єктивно оцінити стан здоров'я та перебігу патологічного процесу в організмі тварин, чільне місие відводиться дослідженню крові. Дослідження біохімічних показників крові дозволяє достовірно 
оцінити стан метаболічних прочесів в організмі тварин, з високою точністю встановлювати не тільки загальний стан організму, а й прогнозувати ускладнення, коректувати їх профілактику та терапію. Мета роботи полягала у вивченні біохімічних показників крові глибокотільних нетелей для прогнозування, корекції і профілактики акушерської патологї в період родів та пуерперію. Дослідження проводились на глибокотільних нетелях голитинської породи, відібраних за принципом аналогів. Біохімічне дослідження сироватки крові проводили в районній лабораторії ветеринарної медииини. У сироватиі крові глибокотільних нетелей були визначені показники білкового та мінерального обміну: загальний білок, каротин, резервна лужність, неорганічний фосфор, вміст альбумінів, імуноглобуліни класу М. Отримані результати досліджень свідчать про те, щзо у глибокотільних нетелей голштинськоі чорно-рябої породи загальний вміст білка відповідає рівню норми, а білковий коефіцієнт перевищує нормативний показник. Встановлені виражені відхилення в біохімічних показниках крові: низький рівень каротину майже в 2 рази, резервної лужності - в 1,91 раза, вмісту загального кальцію - на 16,08\% і співвідночення Кальцію до Фосфору на 17,78\%. Оскільки зниження вмісту каротину корелює зі схильністю до ендометриту, то глибокотільні нетелі голитинської чорно-рябої породи схильні до розвитку родової та післяродової патологї. Доведено, щчо для схильних до родової та післяродової патологї корів несприятливим прогнозом щзодо виникнення слабкої родової діяльності, затримки посліду, субінволюиії матки, ендометриту та післяродової гіпокальціємї є низька концентрація у сироватці крові кальцію загального, фосфору неорганічного та каротину.

Ключові слова: нетелі, вагітність, родова та післяродова патологія, біохімічні показники крові, біохімічне дослідження.

\section{Вступ}

Вагітність - це складний фізіологічний процес в організмі самки, який пов'язаний з плодоносінням, що проходить $з$ моменту запліднення до родів і супроводжується суттєвими навантаженнями на організм матері в зв'язку з формуванням плаценти, а також органів та систем організму плода, що розвивається (Koreyba, 2014; Zhelavskyi, 2017).

У здорових тварин гомеостаз і показники метаболізму підтримуються на постійному рівні, незалежно від терміну вагітності. Одні тварини здатні зберігати оптимальний рівень і якість життєвих процесів у всі фізіологічні періоди життя, тимчасом як у інших недостатньо внутрішніх резервів для ї підтримки (Bomko et al., 2018; Sachuk et al., 2019; Grymak et al., 2020; Mazur et al., 2020; Zhelavskyi et al., 2020). Тому у таких тварин під час вагітності до субклінічних розладів обміну речовин розвиваються зміни гомеостаза. Характер порушень метаболізму в організмі тварин 3 різним фізіологічним станом добре характеризують гематологічні показники (Levchenko et al., 2002; Vlizlo et al., 2012; Zamazii et al., 2015).

У період плодоносіння змінюються основні метаболічні процеси в організмі самки, оскільки збільшується потреба у поживних речовинах і змінюються показники водно-сольового балансу. Нежданов А. Г. (1978 р.) акушерсько-гінекологічну патологію у корів пояснює недостатньою i неповноцінною годівлею, огріхами в утриманні та догляді, несвоєчасним осіменінням тощо. Під впливом несприятливих факторів виникають розлади в статевій системі самок у вигляді зниження регенеративної, гормональної секреторної та моторної функції, що веде до неплідності та вибракування тварин. Дефіцит біологічно активних речовин, а саме мікроелементів та вітамінів, у кормах тварин обумовлює зниження резистентності організму і виникнення хвороб обміну речовин, затримки посліду, ендометритів і маститів (Nezhdanov \& Kuznecov, 1978).

Серед біологічних чинників, що обумовлюють симптоматичну неплідність у самок, значне місце займає акушерська і гінекологічна патологія, яка безпосередньо пов'язана з порушенням обмінних процесів, що виявляються на ранніх стадіях при визначенні біохімічного статусу організму тварин Під впливом несприятливих факторів виникають розлади в статевій системі самок, зокрема зниження регенеративної, гормональної секреторної та моторної функції, що веде до тривалої неплідності, яловості та вибракування тварин (Koreyba, 2014; 2015; Koreyba et al., 2015).

Акушерсько-гінекологічна патологія безпосередньо пов'язана $з$ порушенням обмінних процесів, які виявляються на ранніх стадіях при визначенні біохімічного статусу організму тварин. На думку Нежданова А. Г. (1978 р.), Івашкевича О. П. (2013 р.), Ордіна Ю. Н. (2013 р.), Корейби Л. В. (2015, 2018, 2019 рр.), біохімічний профіль крові у вагітних самок дає можливість визначити функціональну активність фетоплацентарного комплексу, передбачити вірогідність виникнення родових та післяродових ускладнень (Nezhdanov \& Kuznecov, 1978; Hryban et al., 1999; Duda, 2002; Ivashkevich, 2013; Ordin et al., 2013; Koreyba et al., 2015; Korejba \& Duda, 2018; Koreyba, 2019).

Отже, дослідження біохімічних показників крові дозволяє достовірно оцінити стан метаболічних процесів в організмі тварин, з високою точністю встановлювати не тільки загальний стан організму, а й прогнозувати ускладнення, коректувати їхню профілактику та терапію. Це особливо важливо для здійснення контролю метаболічних змін в організмі тварин і прогнозування розвитку акушерської патології вже на початкових термінах вагітності й особливо в період сухостою, коли плід інтенсивно росте й розвивається.

Мета роботи полягала у вивченні біохімічних показників крові глибокотільних нетелей для прогнозування, корекції і профілактики патології родів та післяродового періоду.

\section{Матеріал і методи досліджень}

Дослідження проводили на глибокотільних нетелях голштинської чорно-рябої породи у господарствах Дніпропетровської області, де функціонує цехова система утримання тварин.

Для проведення досліду була сформована група нетелів голштинської породи (30 тварин) на 7-му місяці тільності, відібраних за принципом аналогів.

Зразки крові для проведення лабораторних досліджень відбиралася вранці до годівлі тварин. Біохіміч- 
ні дослідження сироватки крові проводили в районній лабораторії ветеринарної медицини.

Нами були визначені: загальний протеїн - рефрактрометричним методом, каротин - фотометричним методом, резервна лужність за методом Раєвського, Кальцій - комплексонометричним методом, неорганічний Фосфор за реакцією з молібденовим реактивом.

Визначення вмісту альбумінів проводили за стандартним колориметричним методом із застосуванням барвника бромкрезолового зеленого, 3 подальшою колориметрією на фотоелектроколориметрі при довжині хвилі 620-630 нм.

Імуноглобуліни класу $\mathrm{M}$ визначалися методом простої радіальної імунодифузії за Манчіні. Як стандарт використовувалася сироватка 3 раніше встановленим рівнем імуноглобулінів класу М (Москва). Фарбування проводили розчином амідо-чорного барвника 10Б. Облік одержаних результатів досліджень здійснювався шляхом вимірювання діаметрів кілець преципітації штангель-циркулем. Кількість імуноглобулінів М у випробуваній пробі визначалася шляхом порівняння діаметра кільця преципітату навколо лунки з калібрувальної кривої.

Статистичну обробку результатів досліджень проводили методом малих виборок з використанням таблиці Стьюдента.

\section{Результати та їх обговорення}

Усі дослідні тварини перебували в звичайних виробничих умовах, були клінічно здоровими і піддавалися постійному ветеринарному обстеженню. У господарствах проводились ветеринарно-санітарні заходи згідно з планом, складеним на початку року.

Згідно з планом протиепізоотичних заходів у господарствах проводились профілактичні імунізації і діагностичні дослідження, також проводились дослідження на туберкульоз, лейкоз, бруцельоз та гельмінтози.

Ветеринарними фахівцями проводиться акушерсько-гінекологічна диспансеризація маточного поголів'я великої рогатої худоби два рази на рік. Систематично проводяться лабораторні дослідження кормів та крові. Також виконується комплекс заходів, спрямованих на запобігання неплідності - визначення оптимальних термінів осіменіння, чіткий всебічний контроль стану органів статевої системи, проведення діагностичних, лікувальних та профілактичних заходів.

У зв'язку з тим, що досліди проводилися в другій половині стійлового періоду, а також через економічні труднощі в господарствах годівля тварин не завжди була повноцінною, насамперед за вмістом вітамінів і мінеральних речовин, а також перетравлюваного протеїну. Іноді порушувалася і якість кормів.

3 отриманих результатів досліджень у глибокотільних нетелей голштинської чорно-рябої породи видно, що загальний вміст протеїну $(75,60 \pm 5,23$ г/л) відповідає рівню норми (70,00-85,00 г/л).

Співвідношення альбумінів і глобулінів (білковий коефіцієнт) у зв'язку зі достовірно зниженим вмістом останніх $(45,76 \pm 3,02 \%)$ від загального вмісту протеїнів перевищує норму (27,00-58,00 \%) (табл. 1).

Вміст каротину нижчий майже в 2 рази від нижньої межі норми (9,30-18,60 мкмоль/л), і становить $2,79 \pm 0,11$ мкмоль/л.

Отримані результати показників мінерального обміну у глибокотільних нетелей показані на рис. 1. Так, значення резервної лужності в 1,91 раза нижче від норми (4,60-5,80 г/л) для даного періоду тільності і становить $3,0 \pm 0,13$ г/л.

\section{Таблиця 1}

Показники білкового обміну у глибокотільних нетелей $(\mathrm{n}=30)$

\begin{tabular}{cccc}
\hline \multicolumn{2}{c}{ Показники } & $\begin{array}{c}\text { Результати } \\
\text { досліджень }\end{array}$ & $\begin{array}{c}\text { Норма (середне } \\
\text { значення) }\end{array}$ \\
\hline Загальний протеїн, г/л & $75,60 \pm 5,23$ & $\begin{array}{c}70,00-85,00 \\
(77,5)\end{array}$ \\
Альбуміни, & г/л & $41,08 \pm 2,51$ & $40,00-60,00$ \\
Глобуліни, & г/л & $34,52 \pm 1,87$ & $(50,00)$ \\
& $\%$ & $45,76 \pm 3,02^{*} *$ & $27,00-58,00$ \\
& & $1,19 \pm 0,10$ & $(42,50)$
\end{tabular}

Альбуміни/глобуліни $\quad 1,19 \pm 0,10$

Примітка: * $\mathrm{P}<0,05,{ }^{*}{ }^{*} \mathrm{P}<0,01$ щодо середнього значення норми

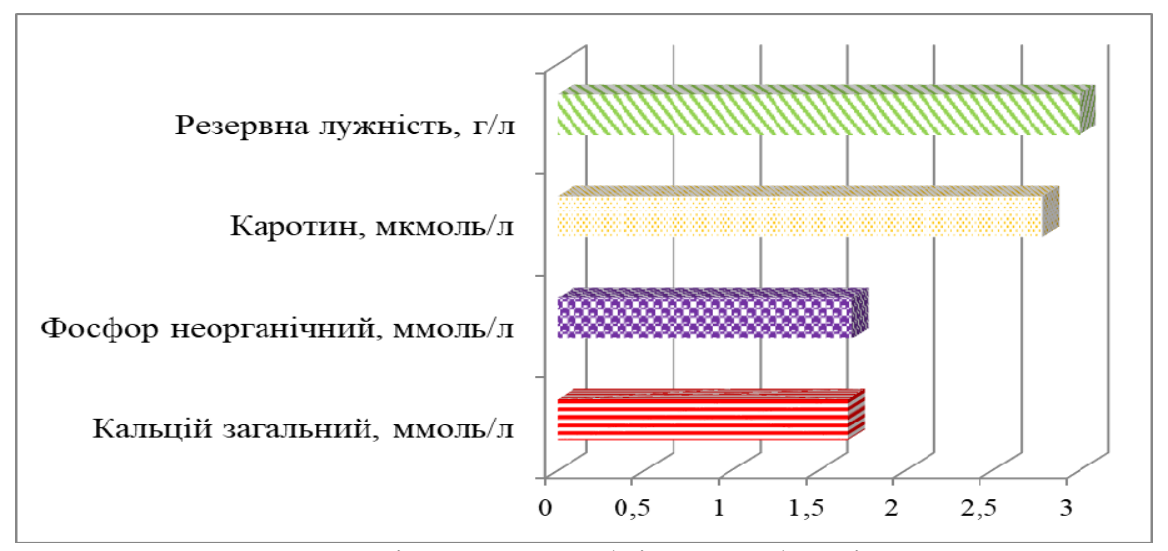

Рис. 1. Показники мінерального обміну у глибокотільних нетелей 
Встановлено, що показник загального Кальцію на $16,08 \%$ нижчий $(1,67 \pm 0,09$ ммоль/л) порівняно 3 показником нижньої межі норми (2,30-3,12 ммоль/л). Вміст Фосфору $(1,72 \pm 0,16$ ммоль/л) - відповідає рівню норми (1,60-2,30 ммоль/л) (рис. 2), проте співвідношення Кальцію до Фосфору знижено на 17,78 \% $(0,98)$ (проти значення 2,0).

Враховуючи той факт, що зниження каротину в сироватці крові призводить до переродження епітелію ендометрію, уповільнення його регенерації (Hryban et al., 1999; Duda, 2002) і корелює зі схильністю до ендометритів (Ivashkevich, 2013; Koreyba, 2015), можна зробити висновок, що нетелі голштинської чорнорябої породи є схильними до розвитку ендометритів.

На другому етапі досліджень була проведена рання акушерська диспансеризації корів у родильному відділенні. На підставі результатів акушерської диспансеризації ми зробили аналіз поширення акушерської патології у корів в умовах господарств.

У період проведення досліджень в умовах господарств патологічний перебіг родів реєстрували у 20 корів-первісток, що складає 66,6 \% від загальної кількості розтелених тварин. Досить часто роди у корівпервісток ускладнювались затримкою посліду. Нерідко акушерську допомогу надавали при патологічних отелах внаслідок слабкості родових переймів і потуг у $10(33,3 \%)$ випадках.

На 7-у добу після отелення діагностували післяродову субінволюцію матки.

За період досліджень післяродову субінволюцію матки та ендометрити реєстрували у 13 (43,3 \%) корів. Ознаки типової і атипової форм післяродового парезу реєстрували на 2-3 добу після отелу у 2 (6,6 \%) тварин.

\section{Висновки}

У глибокотільних нетелів голштинської чорнорябої породи у період тільності встановлено виражені відхилення в біохімічних показниках крові: низький рівень каротину майже в 2 рази, резервна лужність - в 1,91 раза, вміст загального Кальцію - на 16,08 \% і співвідношення Кальцію до Фосфору на 17,78 \%. Оскільки зниження вмісту каротину корелює зі схильністю до ендометриту, то глибокотільні нетелі в умовах господарств Дніпропетровського регіону $\epsilon$ схильними до розвитку післяродової акушерської патології.

Отже, для схильних до акушерської патології корів несприятливим прогнозом щодо виникнення слабкої родової діяльності, затримки посліду, субінволюції матки, ендометриту та післяродової гіпокальціємії є низька концентрація у сироватці крові Кальцію загального, Фосфору неорганічного та каротину.

Перспективи подальших досліджень полягають у вивченні показників клітинного і гуморального імунітету та неспецифічної реактивності організму глибокотільних корів з метою прогнозування, корекції і профілактики акушерської патології.

\section{References}

Bomko, V., Kropyvka, Yu., Bomko, L., Chernyuk, S., Kropyvka, S., \& Gutyj, B. (2018). Effect of mixed ligand complexes of Zinc, Manganese, and Cobalt on the Manganese balance in high-yielding cows during first 100-days lactation. Ukrainian Journal of Ecology, 8(1), 420-425. doi: 10.15421/2018_230.

Duda, Y. V. (2002). Osoblyvosti pryrodnoyi rezystentnosti koriv holshtyns'koyi porody riznoho fiziolohichnoho stanu za vplyvu biolohichno aktyvnykh rechovyn (propolisu ta hidrohumatu). Kyiv (in Ukrainian).

Grymak, Y., Skoromna, O., Stadnytska, O., Sobolev, O., Gutyj, B., Shalovylo, S., Hachak, Y., Grabovska, O., Bushueva, I., Denys, G., Hudyma, V., Pakholkiv, N., Jarochovich, I., Nahirniak, T., Pavliv, O., Farionik, T., Bratyuk, V. (2020). Influence of "Thireomagnile" and "Thyrioton" preparations on the antioxidant status of pregnant cows. Ukrainian Journal of Ecology, 10(1), 122-126. doi: 10.15421/2020_19.

Hryban, V. H., Syedykh, N. Y., Duda, YU. V., \& Syedykh, A. I. (1999). Biokhimichni pokaznyky krovi pislya transportno-aklimatyzatsiynoho stresu u neteliv ta koriv-pershotilok $\mathrm{z}$ pislyapolohovymy endometrytamy. Naukovyy visnyk L'vivs'koyi deozhavnoyi akademiyi veterynarnoyi medytsyny im. S. Z. Hzhyts'koho, 2, 22-24 (in Ukrainian).

Ivashkevich, O. P. (2013). Vliyaniye gomeostaza sukhostoynykh korov na vozniknoveniye rodovoy $\mathrm{i}$ poslerodovoy patologii. Gorki: BGSHA (in Russian).

Korejba, L. V., \& Duda, Ju. V. (2018). Biohimicheskij profil' krovi u korov $\mathrm{s}$ fiziologicheskim i patologicheskim teche-niem poslerodovogo perioda Aktual'nye problemy intensivnogo rvzvitija zhivotnovodstva: materialy HHI Mezhdunarodnoj nauchnoprakticheskoj konferencii. Gorki: BGSHA, 2, 182-185 (in Russian).

Koreyba, L. (2019). Haematological indicators in highproduced cows in dynamics of dry period. Scientific Messenger of LNU of Veterinary Medicine and Biotechnologies. Series: Veterinary Sciences, 21(93), 3740. doi: 10.32718/nvlvet9307 (in Ukrainian).

Koreyba, L. V. (2014). Rodovi ta pislyarodovi uskladnennya u koriv holshtyns'koyi porody $\mathrm{v}$ umovakh $\mathrm{v}$ umovakh PrAT “Ahro-Soyuz” Synel'nykivs'koho rayonu Dnipropetrovs'koyi oblasti. Problemy zooinzheneriyi ta veterynarnoyi medytsyny: zb. nauk. pr. Kharkivs'koyi derzhavnoyi zooveterynarnoyi akademiyi. Kharkivs'ka derzhavna zooveterynarna akademiya. Veterynarni nauky, 29(2), 92-94 (in Ukrainian).

Koreyba, L. V. (2015). Poshyrennya akushers'koyi patolohiyi u koriv holshtyns'koyi porody v umovakh pryvatnoho aktsionernoho tovarystva "Ahro-Soyuz" Synel'nykivs'koho rayonu Dnipropetrovs'koyi oblasti. Problemy zooinzheneriyi ta veterynarnoyi medytsyny: Zbirnyk naukovykh prats' Kharkivs'koyi derzhavnoyi zooveterynarnoyi akademiyi, 30(2), 78-82 (in Ukrainian). 
Koreyba, L. V., Spitsyna, T. L., \& Holub, A. A. et al. (2015). Prohnozuvannya akushers'kohinekolohichnoyi patolohiyi u vysokoproduktyvnykh koriv za biokhimichnymy pokaznykamy krovi. Nauchnye trudy SWorld: mezhdunarodnoe periodicheskoe nauchn. izd. Ivanovo: Nauchnyj mir (in Ukrainian).

Levchenko, V. I., Vlizlo, V. V., \& Konrakhin, I. P. et. al. (2002). Veterynarna klinichna biokhimiya. Bila Tserkva: BNAU (in Ukrainian).

Mazur, N. P., Fedorovych, V. V., Fedorovych, E. I., Fedorovych, O. V., Bodnar, P. V., Gutyj, B. V., Kuziv, M. I., Kuziv, N. M., Orikhivskyi, T. V., Grabovska, O. S., Denys, H. H., Stakhiv, N. P., Hudyma, V. Yu., \& Pakholkiv, N. I. (2020). Effect of morphological and biochemical blood composition on milk yield in Simmental breed cows of different production types. Ukrainian Journal of Ecology, 10(2), 61-67. doi: $10.15421 / 2020110$.

Nezhdanov, A. G., \& Kuznecov, A. I. (1978). Obmen veshhestvu korov pri beremennosti, rodah i poslerodovoj period. Veterinarija, 4, 79-82 (in Russian).

Ordin, Ju. N., Plahotin, I. N., \& Baban', A. A. (2013). Sootnoshenie biohimicheskih pokazatelej krovi korov v norme i akusherskoj patologii. Aktual'nye problemy veterinarnogo akusherstva i reprodukcii zhivotnyh:Materialy mezhdunarodnoj nauchnoprakticheskoj konferencii, posvjashhennoj 75-letiju so dnja rozhdenija i 50-letiju nauchno-prakticheskoj dejatel'nosti doktora veterinarnyh nauk, professora $\mathrm{G}$. F. Medvedeva. Gorki: BGSHA, 210-215 (in Russian). Sachuk, R., Stravsky, Y., Shevchenko, A., Katsaraba, O., Kostyshyn, Y., \& Zhyhalyuk, S. (2019). Distribution, etiology and prevention of subclinical mastitis in cows. Ukrainian Journal of Veterinary and Agricultural Sciences, 2(2), 18-21. doi: 10.32718/ujvas2-2.04.

Vlizlo, V. V., Fedoruk, R. S., \& Ratych, I. B. et al. (2012). Laboratorni metody doslidzhen' u biolohiyi, tvarynnytstvi ta veterynarniy medytsyni. L'viv: SPOLOM (in Ukrainian).

Zamazii, A. A., Kambur, M. D., \& Lisovenko, V. M. (2015). Fiziolohichni vlastyvosti krovi tilnykh koriv. Visnyk Sumskoho natsionalnoho ahrarnoho universytetu. Seriia: Veterynarna medytsyna (in Ukrainian).

Zhelavskyi, M. M. (2017). Ontogenetic features of the formation of local immune protection of the mammary gland of cows (literature review and original research). Scientific Messenger of Lviv National University of Veterinary Medicine and Biotechnologies named after S. Z. Gzhytskyj, 19(79), 3-8. doi: 10.15421/nvlvet7801.

Zhelavskyi, M., Kernychnyi, S., Mizyk, V., Dmytriv, O., \& Betlinska, T. (2020). The importance of metabolic processes and immune responses in the development of pathology of cows during pregnancy and postpartum periods. Ukrainian Journal of Veterinary and Agricultural Sciences, 3(2), 36-41. doi: 10.32718/ujvas3-2.06. 